\title{
PEMAKNAAN RUANG TERBUKA PUBLIK TAMAN NOSTALGIA KOTA KUPANG
}

\author{
Yoseph Liem ${ }^{1}$, Reginaldo Ch. Lake ${ }^{2}$ \\ ${ }^{1}$ Program Studi Magister Arsitektur, Fakultas Arsitektur dan Desain, Universitas Kristen Duta Wacana, \\ ${ }^{2}$ Program Studi Teknik Arsitektur, Fakultas Teknik, Universitas Katolik Widya Mandira \\ Email: 1 liem_architecs@yahoo.com, ${ }^{2}$ egilake@unwira.ac.id
}

\begin{abstract}
Abstrak
Taman Nostalgia Kota Kupang menjadi salah satu ciri kota Kupang sebagai satu-satunya taman yang cukup representatif di kawasan Kota Kupang. Namun jiwa tempat merupakan kekuatan nonfisik yang mampu membentuk kesan dalam kota. Apakah taman Nostalgia berhasil memberi makna sebagaimana konsep awal perencanaan dan pembangunannya guna membawa manfaat yang luas bagi Kota Kupang dan warganya. Oleh karena itu, tujuan penelitian ini adalah untuk mengetahui sejauh mana pemanfaatan taman Nostalgia sebagai ruang publik dan bagaimana maknanya bagi warga kota. Penelitian ini dilakukan dengan metode deskriptif kualitatif. Pengamatan dilakukan diruang taman pada waktu-waktu yang telah ditentukan untuk mendapatkan gambaran pola pemanfaatannya. Adapun hasil penelitian menunjukkan bahwa pemanfaatan ruang terbuka publik taman Nostalgia masih belum maksimal sesuai konsep awal, dimana tujuan pemanfaatan taman pada skala yang lebih besar belum tercapai ditandai dengan belum berhasilnya upaya menjadikan taman sebagai paru-paru kota/hutan kota dan belum memberi makna yang demokratis bagi pengunjung taman sebagai ruang terbuka publik yang bebas dan bisa diakses oleh semua warga terutama oleh pengunjung lanjut usia dan balita.
\end{abstract}

Kata kunci: pemaknaan, ruang terbuka publik, taman nostalgia

\begin{abstract}
Title: The Meaning of Public Space of Kupang City Nostalgia Park

Kupang City Nostalgia Park became one of the characteristics of the city where the park is located in the city center and became the only representative representative park in the city of Kupang. But the soul is unreliable. Is Nostalgic Park able to give meaning to the initial concept of planning and development in order to provide broad benefits for the city of Kupang and its citizens. Therefore, the purpose of the study is to know the extent to which Nostalgia parks as a public space and how its meaning for the citizens of the city. This research was conducted by qualitative descriptive method. Observations were made in the park room at predetermined times to get an overview of the utilization pattern. The results show that the utilization of open space Nostalgia public park is still not maximized according to the initial concept, where the purpose of utilization of the park on a larger scale has not been integrated with the unsuccessful efforts to make the park as the lung of the city / forest city and has not given a democratic meaning to visitors park as a public open space that can be accessed by the visitors.
\end{abstract}

Keywords: meaning, public open space, Nostalgia park 


\section{Pendahuluan}

Sebuah ruang kota seharusnya tidak hanya hadir secara fisik saja akan tetapi dapat memberi nilai lebih atau makna lain bagi kota tersebut. Perkembangan pembangunan sebuah kota tidak lepas dari kebutuhan warga kota akan sarana ruang publik/public space. Kota Kupang awalnya memiliki beberapa ruang publik yang representatif diantaranya arena pameran Fatululi dan Taman Nostalgia. Namun dengan dalil meningkatkan pendapatan asli daerah serta memacu pembangunan dan perkembangan kota maka yang terjadi kemudian adalah, beberapa ruang terbuka publik beralih fungsi menjadi ruang terbuka privat yang berada di bawah kendali konglomerasi. Ruang terbuka publik arena pameran Fatululi yang tadinya berdampingan dengan lokasi Taman Nostalgia perlahan tapi pasti tidak berbekas lagi. Saat ini Taman Nostalgia menjadi satu-satunya taman yang representatif di kawasan Fatululi. Awalnya Taman Nostalgia diproyeksikan sebagai taman hutan kota sekaligus menjadi paru-paru kota, dan arena pameran Fatululi sebagai fungsi ruang publik kota. Namun setelah lebih kurang 12 tahun beroperasi semenjak dibangun ternyata Taman Nostalgia masih belum menampakkan pertumbuhan hutan kota sekaligus sebagai taman edukasi bagi warga Kota Kupang. Taman hutan kota dengan konsep taman edukasi yang partisipatif sebagai tujuan pemerintah kota. Pola yang ingin diterapkan pada taman ini adalah pemerintah sebagai inisiator akan menyediakan bibit-bibit tanaman untuk ditanam oleh pengunjung sebagai kenangan akan kunjungan mereka. Diharapkan warga masyarakat akan berinisiatif pula untuk menjaga, memelihara dan merawat tanamannya sebagai kenangan atau nostalgia dikemudian hari kelak. Gerakan positif ini diawali dengan penanaman tanaman/pohon oleh beberapa Walikota seIndonesia pada saat pencanangannya. Karakter ruang terbuka publik sebagai tempat interaksi warga sangat penting dalam menjaga dan meningkatkan kualitas kawasan perkotaan. Ruang publik di Indonesia memiliki arti yang sangat penting dan strategis secara hukum yaitu dengan ditetapkannya Undang-undang No. 26 tahun 2007 Tentang Penataan Ruang. Dimana dalam pasal 28 ditegaskan perlunya penyediaan ruang terbuka hijau (RTH) dan ruang terbuka non hijau (RTNH) didalam suatu kota.

Kota Kupang saat ini masih belum bisa memenuhi kewajiban 30\% ruang terbuka hijau sesuai amanat Undang-undang. Ruang-ruang publik yang selama ini menjadi tempat warga berkumpul dan melakukan interaksi, seperti lapangan olah raga, taman kota, arena wisata, arena kesenian perlahan tapi pasti mulai menghilang dan digantikan oleh mall, pusat-pusat perbelanjaan dan rukorukan. Disamping itu kondisi ruang publik juga menghadapi masalah kualitas. Menurut William $\mathrm{H}$. Whyte dalam tulisannya yang berjudul "Why many public spaces fail" menyatakan bahwa ruang publik sering terlihat rapi, bersih dan sepi/kosong. Kondisi ini terkesan seolah-olah hendak mengatakan "no people, no problem" (Whyte, 1979). Tetapi ketika ruang publik kosong/sepi atau dirusak maka ruang publik tersebut mungkin ada yang salah dengan desain dan manajemennya. Bagaimana dengan Taman Nostalgia di Kecamatan Kelapa Lima yang berada dipusat Kota Kupang 
dan merupakan satu-satunya taman kota yang representatif? apakah sudah berfungsi dengan baik sebagaimana proyeksi awalnya?. Istilah ruang publik (public space) pernah dilontarkan oleh Kevin Lynch dengan menyebutkan bahwa ruang publik adalah nodes dan landmark yang menjadi alat navigasi didalam kota (Lynch, 1960). Mungkinkah Taman Nostalgia bisa dijadikan nodes atau landmarknya Kota Kupang? Sudahkah Taman Nostalgia menjadi ruang yang responsif, demokratis dan bermakna?. Tujuan penelitian ini adalah ingin dilihat sudah sejauhmana ruang terbuka publik Taman Nostalgia memberi makna bagi Kota Kupang dan warganya.

\section{Metode Penelitian}

Metode yang digunakan dalam melaksanakan penelitian ini adalah metode deskriptif kualitatif. Data dan informasi dikumpulkan melalui kegiatan survei, wawancara, pengamatan, pemetaan dan dokumentasi visual. Untuk menguji keabsahan informasi dilakukan verifikasi baik terhadap informan itu sendiri maupun kepada narasumber. Informasi dianggap valid apabila verifikasi mencapai tahap jenuh, yaitu peneliti mendapatkan jawaban yang sama atau mirip dari sejumlah informan dan narasumber atas pertanyaan yang sama. Hasil penelitian tidak berlaku general (umum) akan tetapi berlaku hanya untuk lokasi penelitian itu sendiri. Batasan lokasi penelitian adalah kawasan ruang terbuka publik Taman Nostalgia di Kawasan Fatululi Kecamatan Kelapa Lima Kota Kupang. Data dan informasi yang didapat di lapangan berdasarkan survei, pengamatan dan pengukuran serta kuisioner dipaparkan dalam bentuk laporan wawancara dan laporan pengamatan. Masing-masing informasi yang diperoleh dikumpulkan dan diberikan koding dan dikategorikan menurut judul kejadian tertentu. Melalui interpretasi ditemukan konsep-konsep pemikiran informan untuk menjawab pertanyaan penelitian tentang: terbuka publik Taman Nostalgia Kota Kupang; seperti apa maknanya bagi Kota Kupang dan warga kota.

\section{Hasil dan Pembahasan}

Letak Taman Nostalgia Kota Kupang yang strategis berada di pusat kota pada kawasan yang perkembangannya cukup padat sebagai pusat pemerintahan dan bisnis. Sisi sebelah Timur taman berbatasan dengan lokasi kantor Dewan Perwakilan Rakyat Daerah Kota Kupang, sebelah Utara berbatasan dengan permukiman penduduk, sisi sebelah Barat berbatasan dengan kantor/pos polisi dan patung kirab, sedangkan sebelah selatan berbatasan dengan jalur jalan Frans Seda, gedung keuangan negara dan Terminal bus antar kota.

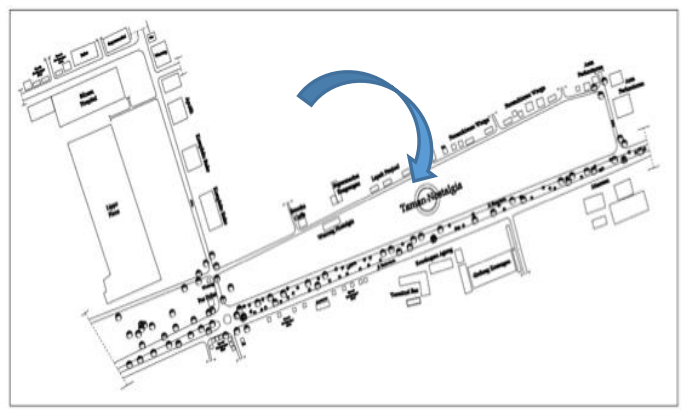

Gambar 1. Peta batasan wilayah studi kasus taman nostalgia kota Kupang 
Lokasi ini awalnya merupakan kawasan kosong yang hanya ditumbuhi pohonpohon flamboyan dan semak belukar. Kondisi tanah berbatu dengan luas total area 5,1 Ha. Taman Nostalgia merupakan upaya pemerintah Kota Kupang Untuk menumbuhkan semangat budaya menanam bagi seluruh warga kota. Selain menikmati arena taman aktif (tempat bersosialisasi, berolah raga dll), pengunjung juga terlibat langsung dalam urusan perlindungan dan konservasi hutan, dimana setiap pengunjung berhak menanam satu atau dua bibit pohon anakan dan memberinya nama. Kegiatan tersebut diharapkan muncul rasa tanggungjawab untuk merawat dan menjaga tumbuhannya hingga besar. Pola yang ingin diterapkan dalam pembuatan Taman Nostalgia sebetulnya adalah pola partisipatif, yakni masyarakat diajak terlibat dalam membangun, terutama dalam hal merawat dan menikmati taman sebagaimana Slamet (2003: 8) menyatakan bahwa, partisipasi masyarakat dalam pembangunan adalah sebagai ikut sertanya masyarakat dalam pembangunan, ikut dalam kegiatankegiatan pembangunan, dan ikut serta memanfaatkan dan menikmati hasil-hasil pembangunan (Slamet, 2003). Untuk keterlibatan dalam menjaga dan merawat keberadaan dan keberlangsungan Taman Nostalgia masyarakat lebih kepada partisipasi sosial atau Social Participation dimana masyarakat terutama yang dipandang sebagai beneficiary atau pihak di luar proses pembangunan dalam konsultasi atau pengambilan keputusan dalam semua tahapan siklus proyek pembangunan dari evaluasi kebutuhan sampai penilaian, implementasi, pemantauan dan evaluasi. Gaventa dan Valderama (1999) dalam
Arsito (2004), mencatat ada tiga tradisi konsep partisipasi terutama bila dikaitkan dengan pembangunan masyarakat yang demokratis yaitu: 1) partisipasi politik Political Participation, 2) partisipasi sosial Social Participation dan 3) partisipasi warga Citizen Participation/Citizenship (Aristo, 2004). Untuk keterlibatan dalam menjaga dan merawat keberadaan dan keberlangsungan Taman Nostalgia masyarakat lebih kepada partisipasi sosial atau Social Participation dimana masyarakat terutama yang dipandang sebagai beneficiary atau pihak di luar proses pembangunan dan hanya sebagai penerima hasil pembangunan semata.

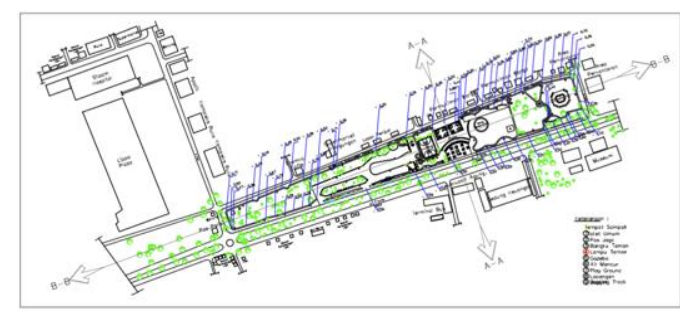

Gambar 2. Layout taman Nostalgia kota Kupang

Tema partisipatif dalam konsep Taman Nostalgia yang direncanakan akan sangat menunjang keberadaan Taman sebagai tempat rekreasi di tengah Kota Kupang yang representatif karena bisa mendatangkan kesejukan dan kenyamanan bagi pengunjung yang berkunjung ke Taman Nostalgia. Dengan demikian dapat meningkatkan fungsi ekologis sebagai paru-paru kota. Sejak awal pembangunan hingga saat ini Taman Nostalgia telah dilengkapi dengan fasilitas atau sarana penunjang kegiatan rekreasi di dalam taman seperti adanya plaza, kolam air mancur, arena bermain anak, lapangan basket mini, joging track, lampu taman, tempat sampah, lopo atau gazebo juga pos 
keamanan. Namun beberapa sarana yang disediakan di taman masih belum ramah bagi pengunjung taman terutama bagi orang lanjut usia dan anak-anak maupun balita yang datang. Terutama pedestrian sebagai joging track dengan level permukaan yang cukup tinggi dari permukaan tanah, kurangnya softscape pada area bermain anak. Selain tidak nyaman untuk beraktifitas dapat berbahaya sebagai sarana rekreasi aktif. Sarana berupa toilet umum hanya berjumlah 3 buah dan dalam kondisi yang kurang terawat sehingga membutuhkan perhatian penuh dari pemerintah Kota Kupang. Fasilitas sarana kebersihan yang memadai sangat diharapkan dalam kawasan taman, karena sebagai taman umum dan terbuka akan banyak sekali faktor penyebab kumuh seperti banyaknya kotoran dan sampah bertebaran dan menyebabkan pemandangan yang tidak menarik dalam taman.

Kenyamanan adalah rasa nyaman untuk tinggal atau beraktifitas di kawasan yang dibentuk termasuk taman didalam beraktifitas membuang sampah yang lebih menarik dengan seting fasilitas yang tidak kaku dan menarik perhatian.

Ruang publik yang responsif menurut Carr (1992) didesain dan diatur untuk melayani kebutuhan pemakainya (Carr, 1992). Selain itu, ruang publik menjadi suatu tempat menemukan hal-hal baru akan dirinya atu orang lain. Di dalam Hidayat (2010) elemen ruang terbuka publik dapat didefinisikan sebagai elemen pembentuk atau pelingkup dan elemen pengisi. Dan vegetasi merupakan elemen yang membentuk dan melingkupi ruang terbuka publik sebagai arah pergerakan, melindungi dari pengaruh sinar matahari angin, penyatu pemandangan terhadap bangunan dan merupakan penghias ruang kota. Sedangkan elemen street furniture merupakan elemen pengisi yang dapat memperkuat citra kawasan. Dari segi sarana dan prasarana kawasan ruang terbuka publik selain menjadi tempat berkumpul, bermain, berolah raga dan bercengkerama bersama keluarga dan teman-teman. Ruang publik atau taman menurut perannya memiliki peran ekonomi, yakni memberi nilai yang positif pada nilai properti, mendororng performa ekonomi regional, dan dapat menjadi bisnis yang baik. Disamping masih ada peran Kesehatan, peran sosial, peran lingkungan, peran methapora dan peran literal (Carmona, 2003).

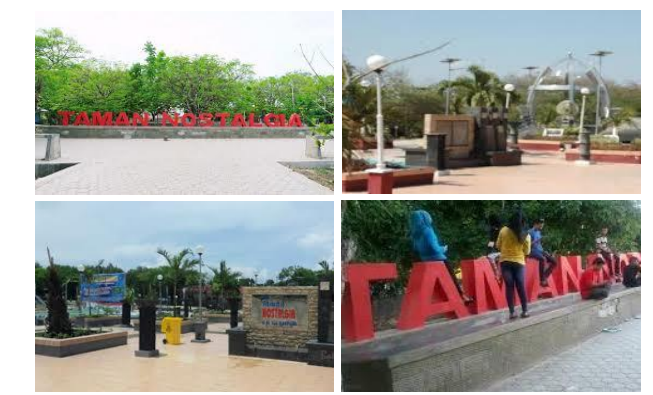

Gambar 3. Tampilan ornamen taman nostalgia kota Kupang

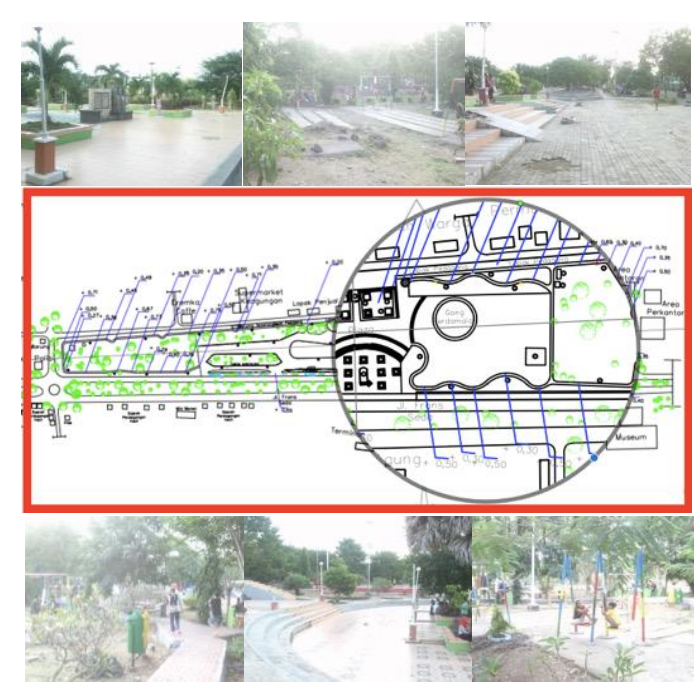

Gambar 4. Fasilitas/sarana taman nostalgia kota Kupang 
Pada peran ekonomi dengan semakin berkembangnya pengunjung dan pemanfaatan taman sebagai sarana berkumpul, berolah raga dan berekreasi maka yang tidak kalah pentingnya adalah tumbuh dan berkembangnya pedagang kaki lima. Saat ini pun pertumbuhan dan perkembangan pedagang kaki lima mulai mewarnai aktifitas lingkungan taman. Pertumbuhan pedagang kaki lima di Taman Nostalgia terutama pada malam hari merupakan fenomena tersendiri disekitar taman karena sebetulnya sejak awal keberadaan seting pedagang kaki lima belum diakomodir sebagai bagian dari unsur taman sehingga kemudian terlihat malah tidak teratur dan liar disekitar taman. Kebutuhan dasar ruang publik seperti kenyamanan, relaksasi, penggunaan pasif, penggunaan aktif dan pengalaman ruang terutama petualangan/keanekaragaman fitur. Pengalaman ruang ini dapat terwujud berupa desain lansekap yang unik, penampilan panorama alami yang menarik, pertunjukan kesenian, kios, dan sebagainya. Perlu sarana dan prasarana dengan perlengkapan ruang publik yang lebih memadai lagi, sehingga dapat memberikan kenyamanan pada pengunjung.

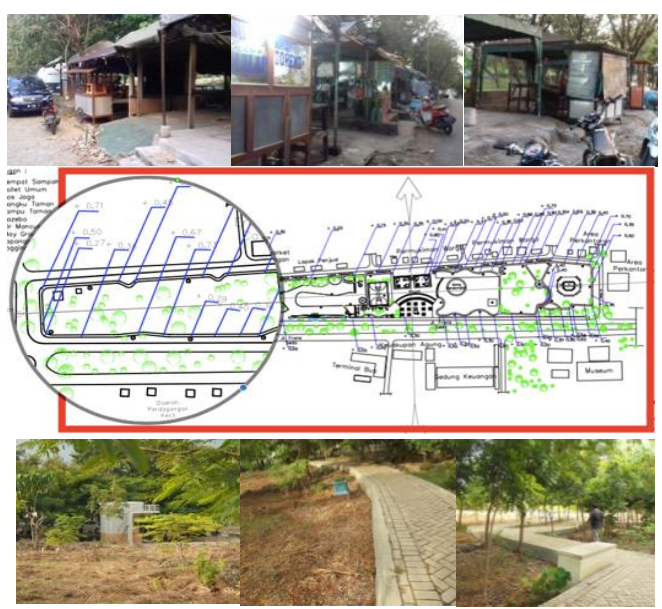

Gambar 5. Tampilan taman nostalgia kota Kupang

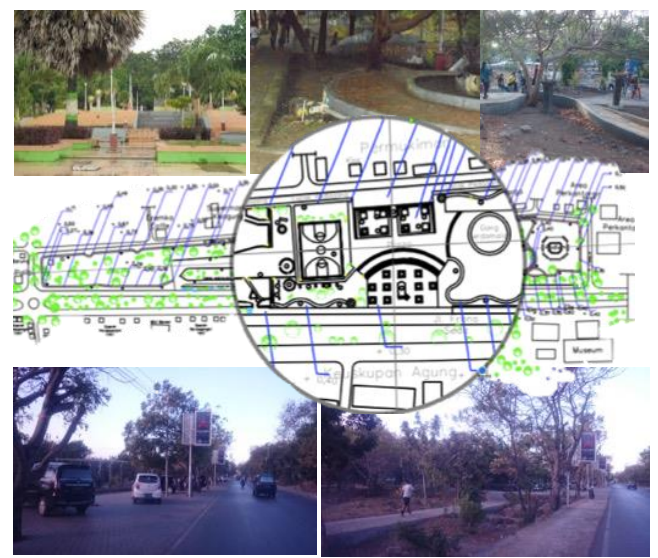

Gambar 6. Fasilita/sarana indikasi tidak aman dalam area taman nostalgia kota Kupang

Seperti bangku-bangku sebagai tempat melepas lelah sejenak setelah berkeliling; shelter sebagai pelindung hujan maupun panas bagi pengunjung yang bermaksud menunggu angkutan umum maupun ketersediaan lavatory umum yang memadai serta terawat dan representatif di kawasan Taman Nostalgia. Taman Nostalgia Kota Kupang secara fisik tidak dilengkapi dengan pagar pembatas masif sejak awal hal ini memungkinkan karena taman ini menjadi benar-benar ruang terbuka yang bisa diakses dengan mudah dari setiap sisinya. 
Keamanan pada ruang publik tidak semata hanya faktor fisik saja karena sebagaimana salah satu dari lima dimensi tampilan (five performance dimensional) Kevin Lynch (1981) yaitu Vitality merupakan suatu kriteria umum yang menitik beratkan pada sistem keamanan, kecocokan ukuran, atau kelayakan antara tuntunan manusia dalam hal temperatur, anatomi tubuh (Lynch, Good City Form, 1981). Kebutuhan akan tingkat kenyamanan pengunjung pada Taman Nostalgia adalah merupakan hal yang utama dikarenakan tujuan dan keinginan berkunjung ke sebuah ruang publik atau ruang terbuka publik adalah untuk menikmati ruang tersebut.

Dalam hal ini kenyamanan ruang publik antara lain dipengaruhi oleh; kenyamanan lingkungan berupa perlindungan dari pegaruh alam seperti sinar matahari, angin dan kenyamanan fisik yang berupa ketersediaanya fasilitas penunjang yang cukup seperti tempat duduk serta keamanan dan kenyamanan secara sosial psikologi. Kondisi Taman Nostalgia ada dua aspek yang mempengaruhi keamanan aktifitas taman terutama bagi pengunjung taman, diantaranya kondisi jalur jalan utama (jalan Frans Seda yang adalah jalur cepat) yang harus diantisipasi agar bisa lebih memberi rasa aman bagi pengunjung.

Baik itu rasa man dari insiden kecelakaan maupun rasa aman dari adanya polusi udara dari kendaraaan bermotor di jalan raya. Sedangkan dari internal taman ada banyak fasilitas yang perlu menyesuaikan dengan vitalitasnya Kevin Lynch dimana adanya suatu sistem keamanan, kecocokan ukuran pada sarana atau fasilitas penunjang, temperatur atau penyesuaian suhu udara dengan tanaman pelindung dan penyejuk serta terkait sistem penerangan taman dimalam hari dikarenakan area taman yang sangat terbuka dari segala sisi sehingga apabila penerangannya kurang maksimal maka akan memberi rasa tidak aman bagi pengunjung yang ingin berkunjung disore maupun malam hari. Hamid Shirvani (1985) menetapkan enam kriteria desain tak terukur antara lain pencapaian, kecocokan, pemandangan, identitas, rasa dan kenyamaan (Shirvani, 1985). Dari kegiatan survei lapangan berupa survei fisik dengan pendataan dan pengukuran serta survey kuesioner dengan penjaringan pendapat dan saran dari pengunjung maupun warga sekitar Taman Nostalgia Kota Kupang, didapat informasi dan data yang beragam yang berhubungan dengan tingkat kenyamanan yang tercipta di dalam area ruang terbuka publik. Taman Nostalgia. Letak taman yang strategis memungkinkan untuk mengalami peningkatan dimasa yang akan datang, kondisi ini tidak saja dipicu oleh semakin padatnya kawasan ini akan tetapi juga karena keberadaan beberapa fasilitas seperti; adanya lingkungan permukiman disisi utara taman, adanya terminal bus antar kota antar negara disisi sebelah selatan dan beberapa fasilitas publik lainnya disebelah barat taman. 


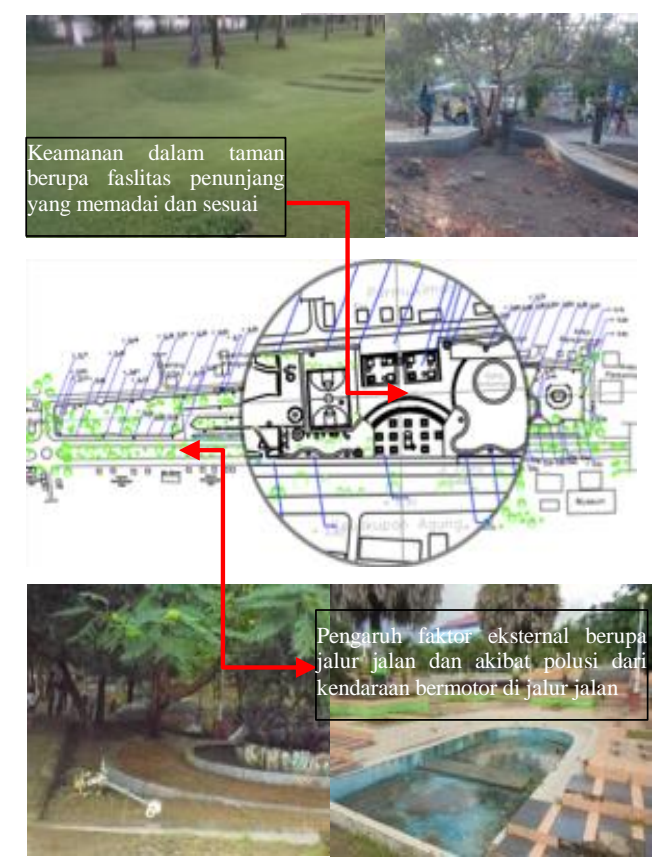

Gambar 7. Fasilitas/sarana indikasi tidak nyaman dalam area taman nostalgia kota Kupang

Aktifitas di taman Nostalgia saat ini lebih didominasi Activity support, dimana semua kegiatan yang memperkuat ruang publik. Bentuk, lokasi dan karakteristik dari area untuk memberikan fungsi dan penggunaan serta aktifitas yang spesifik.

Hal ini terlihat dari fasilitas maupun pergerakan alur kegiatan di dalamnya yang lebih mengarah dan mengakomodasi kegiatan-kegiatan aktifitas aktif atau berolah raga bagi pengunjung. Menurut Cooper. 1998:23 menyatakan bahwa Ukuran utama keberhasilan dari ruang publik adalah pemanfaatannya, sedangkan pemanfaatan dan kepopuleran sebuah ruang publik tergantung lokasi dan detail dalam rancangannya (Cooper, 1998). Dalam hal ini keduanya harus lebih terkomunikasikan yaitu keterkaitan antara rancangan seting fisik dengan pemanfaatan ruang publik, sehingga ruang publik tersebut memiliki daya tarik tersendiri bagi masyarakat untuk memanfaatkan dan beraktifitas. Apakah Taman Nostalgia dapat dikatakan Demokratis? Taman Nostalgia secara fisik tampil sebagaimana klasifikasi taman dan ruang terbuka yang menurut Steiner dan Butler dalam Suparyanti (2008) adalah: Community Park, merupakan taman kota dengan lingkup pelayanannya lebih besar dari taman lingkungan (Neighborhood Park). Fungsi utama sebagai tempat pertemuan, pemenuhan terhadap sarana rekreasi untuk melindungi keunikan lansekap dan ruang terbuka kawasan. Atau parkway, yang merupakan taman berbentuk linier sepanjang koridor jalan yang menghubungkan taman umum, monument, instansi, dan pusat bisnis (Suparyanti, 2008). Taman ini dapat berupa ruang hijau atau disesuaikan dengan karakter alamiahnya. Hasil survei menunjukan dari profil responden yang muncul keterwakilan kunjungan terbesar diwakili oleh kelompok mahasiswa (dewasa) 52\% yang sesuai pengamatan adalah dengan aktifitas pasif duduk-duduk bercengkerama dan aktifitas aktif dengan berolah raga dan joging dijalur pedestrian. Sedangkan urutan kedua adalah pegawai swasta yang terdiri dari anak-anak muda juga sebesar $14 \%$ dengan aktifitas berkumpul dan melepas lelah setelah berkegiatan dikantor dan lapangan. Yang berikut adalah profil dari kelompok pelajar dan pengusaha yang berada di posisi $12 \%$ mereka ini mengisi waktu luang dan berolah raga di dalam area Taman Nostalgia. Dari tabulasi hasil kuesioner yang telah dihimpun dan dianalisa sesuai pertanyaan yang diajukan mengenai kriteria taman dengan indikator optimalisasi pemanfaatannya maka 
respon atas pertanyaan kuisioner adalah sebagaimana ditunjukan dalam chart berikut: Pendapat yang sangat setuju pemanfaatan taman secara optimal adalah sebesar: 32, 60\% sedangkan yang menjawab cukup setuju: 7, 20\% menjawab setuju : 28, 60\% yang memberi jawaban netral sebesar: 16, 20\% Tidak setuju: 3,00\% kurang setuju: 7, 80\% dan yang menjawab sangat tidak setuju : 4,60\% Dari jawaban diketahui bahwa Taman Nostalgia masih menjadi satu-satunya taman yang cukup representatif di Kota Kupang baik karena letaknya dan aksesnya. Minat berkunjung pengguna tamanpun tidak dalam volume yang tinggi karena kebanyakan responden hanya mengunjungi taman di akhir pekan atau hari libur selain karena aktifitas rutin lainnya, juga dikarenakan pengunjung merasa tidak ada hal luar biasa atau menarik yang bisa didapat lagi pada kunjungan-kunjungan berikutnya. Responden juga merespon pertanyaan akan fasilitas taman yang masih belum memadai diantaranya kondisi vegetasi yang merupakan pelindung, peneduh, penyejuk dan sebagai petualangan didalam taman. Kondisi fasilitas taman yang kurang terawat, kondisi toilet umum yang masih terbatas jumlahnya serta tidak tersedianya air. Kebanyakan responden hanya menikmati aktifitas aktif didalam taman dengan berolahraga dan duduk di sekitar taman.

\section{Kesimpulan}

Taman Nostalgia masih belum bisa dikatakan responsif karena tidak bisa menjadi tempat untuk menemukan halhal baru atau ide-ide baru sehingga layak dikatakan sebagai tempat untuk mencari inspirasi. Sebaliknya sebagai ruang publik yang mempunyai arti atau makna maka Taman Nostalgia sebagai satusatunya taman di lokasi yang strategis dan memiliki akses yang luas menjadi pilihan pertama karena warga belum punya alternatif taman lain yang memiliki kriteria yang sama.

Menjawab Taman Nostalgia sebagai taman atau ruang publik yang demokratis, sejauh ini taman ini masih belum bisa melindungi hak-hak kelompok pemakainya. Karena seharusnya ruang publik dikatakan demokratis apabila ruang publik tersebut dapat dipakai oleh semua kelompok dan memberikan kebebasan bertindak bagi pemakainya sehingga untuk sementara mereka dapat memiliki ruang publik tersebut. Taman Nostalgia masih belum bisa diakses dan dinikmati apalagi merasa memiliki oleh orang-orang lanjut usia atau lansia dan anak-anak dibawah lima tahun atau balita. Hal ini disebabkan karena desain taman dengan fasilitasnya. Selanjutnya catatan tambahan yang dapat menambah kesimpulan diatas adalah: pemaknaan ruang publik kota yang ada pada taman Nostalgia Kota Kupang bisa berubah karena perubahan pemanfaatan dan pemaknaan tempat yang bersangkutan sehingga kekuatan pemahaman tentang obyek pada tingkatan perencanaan awal yang dilakukan untuk membangun, membentuk, dan menghasilkan pewadahan dalam ruang publik taman Nostalgia sesuai pemaknaannya yaitu sebagai taman edukasi hutan kota belum berhasil diwujudkan saat ini. 


\section{Daftar Pustaka}

Aristo, D. A. (2004). Rejuvinasi Peran

Perencana Dalam Menghadapi Era

Perencanaan Partisipatif "Sebuah

Tahapan Awal dalam Pembentukan

Kultur Masyarakat Partisipatif".

Seminar Tahunan ASPI (Asosiasi

Sekolah Perencanaan Indonesia).

Malang: Universitas Brawijaya.

Carmona, M. (2003). Public Place Urban Spaces the Dimensions of Urban Design. Amsterdam: Amsterdam Architectural Press.

Carr, S. (1992). Public Space. Cambridge: Press Syndicate of University.

Cooper, C. (1998). All People Place: Design Guidelines For Urban Design Open Space. New York: Van Nostrand Reinhold.

Lynch, K. (1960). The Image of the City. Cambridge: The MIT Press.

Lynch, K. (1981). Good City Form. Massachusetts, EEUU: The MIT Press.

Shirvani, H. (1985). The Urban Design Process. New York: Van Nostrand Reinhold.

Slamet, M. (2003). Membentuk Pola Perilaku Manusia Pembangunan. Bogor: IPB Press.

Suparyanti, Y. (2008). Arah Pengembangan Taman Untuk Anak Usia Prasekolah Di Kota Surabaya. Surabaya: Institut Teknologi Sepuluh Nopember. 